\title{
A RAPID METHOD OF STANDARDIZATION OF THE SHEEP-CELL SUSPENSION USED IN THE HARRISON- WYLER WASSERMANN TECHNIQUE
}

\author{
BY
}

\author{
I. N. ORPWOOD PRICE and A. E. WILKINSON \\ From the Whitechapel L.C.C. Clinic, London
}

In reactions such as the Wassermann, in which several biological components interact, it is desirable that each reagent employed should be standardized as far as possible so that the test can be carried out under conditions which can be reproduced from day to day.

In his description of the Harrison-Wyler Wassermann technique, Wyler (1929) recommended standardization of the sheep-cell suspension by means of hæmoglobin estimations. This is done on a concentrated suspension which is subsequently diluted down to the appropriate density. This method is time-consuming in that several estimations may have to be carried out before an exact match can be obtained. Sensitization of red cells by hæmolytic immune body is a phenomenon which occurs at the cell surface, but the hæmoglobin concentration does not give a measure of the total surface area available to the amboceptor. A more

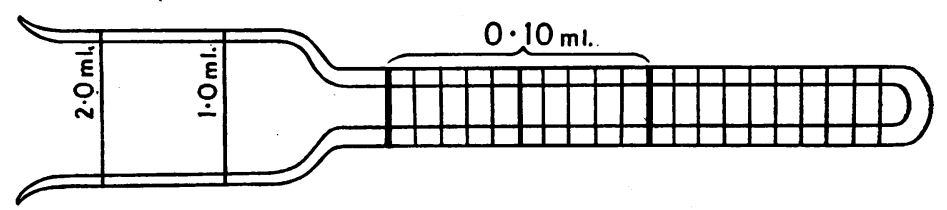
accurate estimate of this area may be obtained by measuring the packed-cell volume by means of a hæmatocrit, and this forms the basis of the method described.

The sheep cells are centrifuged, the deposit re-suspended in about four times the volume of 0.85 per cent. saline, and spun, the washing and spinning being repeated a minimum of four times, or until the supernatant fluid is perfectly clear and colourless. An approximately 6 per cent. suspension of the packed cells is made in 0.85 per cent. saline and exactly $1.0 \mathrm{ml}$. transferred to the hæmatocrit tube with a $1 \mathrm{ml}$. graduated pipette. The bulb of the hæmatocrit* has a capacity of $2.0 \mathrm{ml}$., and the stem $0.2 \mathrm{ml}$. graduated in divisions

* The hæmatocrit tube was made for us by Messrs. R. B. Turner and Co., Ltd., London. of $0.01 \mathrm{ml}$. It is centrifuged for ten minutes at a speed of 2,500 revolutions per minute, which, with the instrument in use, has been found to pack the cells to a constant volume. The height of the column of packed cells is read off, and by simple proportion the factor for dilution of the original 6 per cent. suspension to any desired density is obtained. In this laboratory a packed cell volume of $0.05 \mathrm{ml}$. is taken as the standard. The calculation is shown most easily by an actual example :

$6 \%$ suspension-packed cell volume $0.057 \mathrm{ml}$.

Required packed cell volume $\quad 0.050 \mathrm{ml}$. Dilution factor 0.057

$$
\overline{0.050}
$$

that is $0.14 \mathrm{ml}$. saline should be added to each $1.0 \mathrm{ml}$. of the original 6 per cent. cell suspension.

Equal volumes of the standardized suspension, and 0.85 per cent. saline containing 12 M.H.D. amboceptor per unit volume are mixed, shaken vigorously, and then placed in a $37^{\circ} \mathrm{C}$. water bath. A current of air is drawn through the mixture for thirty minutes by means of a water pump. This keeps the suspension in a state of continuous agitation and ensures even sensitization of the cells. The final concentration of the cells in the cent., and it contains an average of 600,000 cells per c.mm. The method described has been used in this laboratory for six months and it has given consistently reliable results.

\section{REFERENCE}

Wyler, E. J. (1929). M.R.C. Spec. Rep. Series, No. 129. sensitized suspension is approximately 2.5 per 